


\title{
ANTIMICROBIAL ACTIVITY OF CRUDE ETHANOLIC EXTRACTS FROM SOME MEDICINAL MUSHROOMS
}

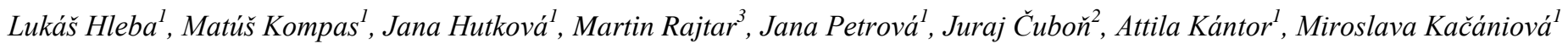

Address(es): Ing. Lukáš Hleba, PhD.,

${ }^{1}$ Slovak University of Agriculture, Faculty of Biotechnology and Food Sciences, Department of Microbiology, Tr. Andreja Hlinku 2, 94976 Nitra, Slovakia.

${ }^{2}$ Faculty of Biotechnology and Food Sciences, Department of Animal Products Evaluation and Processing, Tr. Andreja Hlinku 2, 94976 Nitra, Slovakia.

${ }^{3}$ Mykoforest Martin Rajtar, Velčice 133, 95171 Velčice, Slovakia.

*Corresponding author: lukas.hleba@gmail.com

doi: 10.15414/jmbfs.2016.5.special1.60-63

\section{ARTICLE INFO}

Received 17. 12. 2015

Revised 22. 1. 2016

Accepted 28. 1.2016

Published 8. 2. 2016

Regular article

open $\partial_{\text {ACCESS }}$

\begin{abstract}
In this paper the antimicrobial activity of 1 year old crude ethanolic extracts obtained from Cordyceps sinesis, Laricifomes officinalis, Oudemansiella mucida and Coprinus comatus were investigated. The antimicrobial activities of extracts against two Gram-positive bacteria (Bacillus thuringiensis, Staphylococcus aureus) and two Gram-negative bacteria (Klebsiella pneumoniae, Enterobacter aerogenes) were determined by disk diffusion and microbroth dilution method according by EUCAST in 96-well microplates. Microorganisms were obtained from Czech Collection of Microorganisms. Absorbance after and before the experiment were substracted, converted to binary system and obtained values to Probit analysis were used. Not all macromycetes ethanolic extracts showed antimicrobial activity against tested bacteria. Antimicrobial activity determined by MIC methodology showed extracts from Oudemansiella mucida, Cordyceps sinesis, Coprinus comatus in the tested range. Conversely, the best antimicrobial activity tested by disc diffusion methods showed extract from Laricifomes officinalis. Equally, more better studying of antimicrobial activity in these mushrooms will needed.
\end{abstract}

Keywords: Antimicrobial activity, macromycetes ethanolic extracts, MIC, edible mushrooms

\section{INTRODUCTION}

Nature is a very good source of many medical compounds for thousands of years. In the last decades problem with antibiotic resistant bacteria has emerged. Bacterial pathogens have evolved numerous defense mechanisms against antimicrobial agents, and nowadays, the need to discover new and more potent of these agents as accessories or alternatives to antibiotic therapy is stronger (Butler et al., 2004; Lam et al., 2007). Macromycetes as higher fungi are rich sources of biologically active compounds with an enormous variety of chemical structures. Therefore, mushrooms could be useful in the search of new potent antimicrobial agents (Alves et al., 2012). Mushrooms need antibacterial compounds to survive in their natural environment. It is therefore not surprising that antimicrobial compounds with more or less strong activities could be isolated from many mushrooms and that they could be of benefit for human (Lindequist et al., 1990). There is many different studies about antimicrobial activity of different types of fungal extracts from India (Seena et al., 2003; Quereshi et al., 2010 ) and China (Gao et al., 2005). In this country fungi medicine has tradition for many years ago. For example, Ganoderma lucidum is a one of the most famous traditional medicinal fungi, being used as functional food and in preventive medicines, mostly in the form of extracts with an annual global market (Sullivan et al.,
2005; Pala et al., 2011). But only compounds from microscopic fungi are on the market as antibiotics till now (Lindequist et al., 2005).

The present work is focus to antimicrobial activity of 1 year old medicinal mushrooms extracts isolated from Cordyceps sinesis, Laricifomes officinalis, Oudemansiella mucida and Coprinus comatus against some selected Grampositive and Gram-negative bacteria.

\section{MATERIALS AND METHODS}

\section{Fungi materials}

The fungi materials used in this experiment consist from SSF (Solid State Fermentation) of Cordyceps sinesis and fruiting bodies (basidiocarps) of Laricifomes officinalis, Oudemansiella mucida and Coprinus comatus. Dried fungi SSF and fruiting bodies were obtained from Mykoforest company, Slovakia. Selected fungi were identified by Martin Rajtar (Mykoforest, Slovakia). Fungi were dried at the room temperature in the dark. More detailed information are showed in Table 1

Table 1 Additional information about tested fungi

\begin{tabular}{llllll}
\hline \hline Orig. Latin title & Fungal part & Yield* & Origin & Dissolving time & Extracted by \\
\hline \hline Cordyceps sinesis & SSF & 0.1006 & Mykoforest & & \\
Laricifomes officinalis & fruiting body & 1.7269 & Mykoforest & 1 year at room & Vacuum evaporator from methanol \\
Oudemansiella mucida & fruiting body & 1.0893 & Mykoforest & temperature & at room temperature at -800 mbar \\
Coprinus comatus & fruiting body & 0.3379 & Mykoforest & & \\
\hline * Obtained yield of evaporated ethanolic extracts in g, SSF - Solid state fermentation & & \\
\hline
\end{tabular}

\section{Test microorganisms}

Four strains of microorganisms were tested in this research. Two Gram-negative bacteria include Klebsiella pneumoniae CCM 2318, Enterobacter aerogenes
CCM 2531, two Gram-positive bacteria include Staphylococcus aureus subsp. aureus ser. a5 CCM 2461, Bacillus thiringiensis CCM 19. All tested strains were collected from the Czech Collection of Microorganisms. The bacterial suspensions were cultured in the nutrient broth (Imuna, Slovakia) at $37{ }^{\circ} \mathrm{C}$, expect Bacillus thiringiensis which was cultivated at $30^{\circ} \mathrm{C}$. 


\section{Preparation of fungal extracts}

After drying, the fungal materials were crushed, weighed out to $10 \mathrm{~g}$ and soaked separately in $100 \mathrm{~mL}$ of ethanol p.a. (99,5\%, Sigma, Germany) during 1 year at room temperature in the dark. Why one year? The main reason was determining of antimicrobial activity after the long time of storage. Exposure to sunlight was avoided to prevent the degradation of active components. Then, ethanolic fungal extracts were subjected to evaporation under reduced pressure at $40{ }^{\circ} \mathrm{C}$ in order to remove the ethanol (Stuart RE300DB rotary evaporator, Bibby scientific limited, UK, and vacuum pump KNF N838.1.2KT.45.18, KNF, Germany). For the antimicrobial assay, the crude fungal extracts were dissolved in dimethyl sulfoxid (DMSO) (Penta, Czech Republic) to equal $102.4 \mathrm{mg} / \mathrm{mL}$ as stock solution. Stock solutions of fungal extracts were stored at $-16^{\circ} \mathrm{C}$ in refrigerator until use.

\section{Preparation of discs and disc diffusion method}

Synchronously with evaporation of ethanol from mushroom extract blank discs (Oxoid, UK) were added to extracts and impregnated with extracts. Discs stayed in extracts until evaporated completely. Obtained impregnated discs served as pre-determination experiment for detection of antimicrobial activity. Concentration of extracts in discs were unknown. Impregnated discs were used for disc diffusion methodology, which was done on Mueller-Hinton agar (Biolife, Italy) at $37^{\circ} \mathrm{C}$ for three bacteria, expect Bacillus thuringiensis $\left(30^{\circ} \mathrm{C}\right)$ during 16 20 hours. Bacterial inoculum in physiological solution at the final density of 0,5 $\mathrm{McF}^{\circ}$ was spread out on the agar surface evenly. Impregnated discs were stacked on to the agar surface evenly with adequate spacing. Inhibition zones were read in millimeter.

\section{Antimicrobial assay}

The minimum inhibitory concentration (MIC) is the lowest concentration of the sample that will inhibit the visible growth of microorganisms. Fungal extracts dissolved in DMSO were prepared to a final concentration of $4096 \mu \mathrm{g} / \mathrm{mL}$. Minimum inhibitory concentrations (MICs) were determined by the microbroth dilution method according to the Clinical and Laboratory Standards Institute recommendation (CLSI, 2009) in Mueller Hinton broth (Biolife, Italy) for bacteria. Briefly, the DMSO fungal extracts solutions were prepared as serial two-fold dilutions, in order to obtain a final concentration ranging between 2 $4096 \mu \mathrm{g} / \mathrm{mL}$. Each well was then inoculated with microbial suspension at the final density of $0.5 \mathrm{McF}^{\circ}$. After incubation at $37{ }^{\circ} \mathrm{C}$ for three bacteria and $30{ }^{\circ} \mathrm{C}$ for Bacillus thuringirnsis during 16-20 hours. The inhibition of microbial growth was evaluated by measuring the well absorbance at $590 \mathrm{~nm}$ in an absorbance microplate reader Biotek EL808 with shaker (Biotek Instruments, USA). The 96 micro-well plates were measured before and after experiment. Differences between both measurements were evaluated as growth. Measurement error was established for 0.05 values from absorbance. Wells without fungal extracts were used as positive controls of growth. Pure DMSO was used as negative control. This experiment was done in eight-replicates for a higher accuracy of the minimum inhibitory concentrations of used fungal extracts.

\section{Statistical analysis}

Using obtained absorbance before and after the analysis, we were able to express the differences in absorbance between the measurements as a set of binary values. These values were assigned to exact concentrations. The following formula was created for this specific experiment: value 1 (inhibitory effect) was assigned to absorbance values lower than 0.05 , while value 0 (no effect or stimulant effect) was assigned to absorbance values higher than 0.05 . For this statistical evaluation Probit analysis in Statgraphic software was used.

\section{RESULTS AND DISCUSSION}

\section{Disk diffusion method}

Results from disc diffusion tests showed antimicrobial activity in the case of extracts from Laricifomes officilnalis and Oudemansiella mucida. Some authors (Anke et al., 1979; Anke et al., 1990; Florianowicz et al., 1999) presented results that extract from Oudemansiella mucida inhibited only fungal cells. In their study, scientists determined that main compounds strobilurins and oudemansins inhibited growth of yeasts like Candida albicans, C. glabrata, $C$ krusei and $C$. tropicalis. In our study we determined inhibition effect against Staphylococcus aureus too, which is showed in Figure 1 D, sample 9. Inhibition zone $(12 \mathrm{~mm})$ around Oudemansiella mucida extract was formed in the case of Staphylococcus aureus only. Extracts from Laricifomes officinalis had inhibitory activity against the all used bacterial strains in this experiment. Inhibition zones around the Laricifomes officinalis extract were formed in the case of Staphylococcus aureus $(27 \mathrm{~mm})$, Bacillus thuringiensis $(13 \mathrm{~mm})$, Klebsiella pneumoniae $(20 \mathrm{~mm})$ and Enterobacter aerogenes $(20 \mathrm{~mm})$. Other used macromycetes extracts in this study didn't showed antimicrobial activity. In the other side authors like Demir and Yamac, 2008 tested Coprinus comatus basidiocarp extract dissolved in different solutions and they determined its antimicrobial activity against Staphylococcus aureus, Enterococcus faecium Proteus vulgaris and Candida glabrata. They tested submerged mycelium and some exopolysacharides from Coprinus comatus, but they didn't determined so extensive activity like in previous test with basidiocarps. Inhibition zones are showed on the Figure 1.

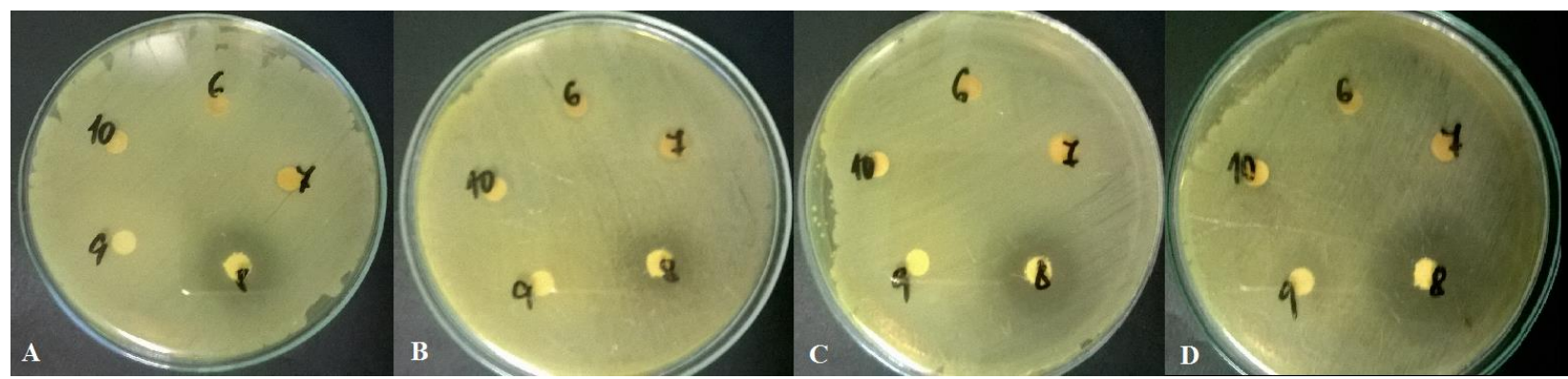

Figure 1 Inhibition zones formed around fungal extract discs (A) Klebsiella pneumoniae, (B) Bacillus thuringiensis, (C) Enterobacter aerogenes, (D) Staphylococcus aureus, (6) Coprinus comatus, (7) Cordyceps sinensis, (8) Laricifomes officinalis, (9) Oudemansiella mucida and (10) not presented extract in this study

\section{Minimal inhibition concentration}

The antimicrobial activity (expressed as $\mu \mathrm{g} / \mathrm{mL}$ ) of four ethanolic fungal extracts from Cordyceps sinesis, Laricifomes officinalis, Oudemansiella mucida and Coprinus comatus against four strains of bacteria are summarized in Table 2 . The most effective was tested fungal extract from Coprinus comatus agains Enterobacter aerogenes with a MIC 50 value $2048 \mathrm{ug} / \mathrm{mL}$. Also, Oudemansiella mucida extract showed inhibitory activity against tested bacteria. Extract from Laricifomes officinalis inhibited the growth of all bacterial strains tested by disk diffusion method, but minimal inhibition concentration method didn't showed any inhibition activity in tested concentration range. Some studies abou antimicrobial activity of Cordyceps sinensis determined that main compounds cordycepin had effects against Clostridium perfringens, C. paraputrificum, Bifidobacterium spp. and Lactobacillus spp. (Kniefel et al., 1977; Ahn et al. 2000). There are exist many studies about antimicrobial activity of higher fung (Yoon et al., 1994; Rosa et al., 2003; Poucheret et al., 2006; Molitoris 1994; Lindequist et al., 2005) because is known that mushrooms need antibacterial and antifungal compounds to survive in their natural environment. It is therefore not surprising that antimicrobial compounds with more or less strong activity could be isolated from many mushrooms and that they could be of benefit for human (Lindequist et al., 1990). But only compounds from microscopic fungi are on the market and antibiotics till now (Lindequist et al., 2005). 
Table 2 The minimum inhibitory concentration (MIC) of ethanolic fungal extracts on four test bacteria

\begin{tabular}{|c|c|c|c|c|c|c|c|c|}
\hline \multirow{3}{*}{ Tested bacteria } & \multicolumn{8}{|c|}{ Antimicrobial activity of macromycetes fungal extract (ug/mL) } \\
\hline & \multicolumn{2}{|c|}{ Cordyceps sinensis } & \multicolumn{2}{|c|}{$\begin{array}{c}\text { Laricifomes } \\
\text { officinalis }\end{array}$} & \multicolumn{2}{|c|}{$\begin{array}{c}\text { Oudemensiella } \\
\text { mucida }\end{array}$} & \multicolumn{2}{|c|}{ Coprinus comatus } \\
\hline & MIC 50 & MIC 90 & MIC 50 & MIC 90 & MIC 50 & MIC 90 & MIC 50 & MIC 90 \\
\hline \multicolumn{9}{|l|}{ Gram-positive bacteria } \\
\hline Bacillus thuringiensis CCM & $>4096$ & $>4096$ & $>4096$ & $>4096$ & 3064,03 & 3257,04 & $>4096$ & $>4096$ \\
\hline Staphylococcus aureus CCM & 4096 & $>4096$ & $>4096$ & $>4096$ & 4096 & $>4096$ & 3064,03 & 3257,04 \\
\hline \multicolumn{9}{|l|}{ Gram-negative bacteria } \\
\hline Klebsiella pneumoniae CCM & 4096 & $>4096$ & $>4096$ & $>4096$ & 3064,03 & 3257,04 & 3064,03 & 3257,04 \\
\hline Enterobacter aerogenes CCM & 3064,03 & 3257,04 & $>4096$ & $>4096$ & 3064,03 & 3257,04 & 2048 & 2285,99 \\
\hline
\end{tabular}

Legend: Abr. - abbreviations,

\section{CONCLUSIONS}

In conclusion, we can state that the ethanolic fungal extracts of all fung (Cordyceps sinesis, Laricifomes officinalis, Oudemansiella mucida and Coprinus comatus) showed antimicrobial activity in high concentration. Very interesting in this experiment was that extract from Laricifomes officinalis showed stronges antimicrobial activity detected by disk diffusion methodology and not by MIC methodology. We think that more studies and experiments and more range of concentration of fungal extracts are needed for better information about antimicrobial activity of macro fungal extracts

Acknowledgements: This work was funded by VEGA 1/0611/14 and APVV0304-12.

\section{REFERENCES}

Ahn, Y. J., Park, S. J., Lee, S. G., Shin, S. C., \& Choi, D. H. (2000). Cordycepin: Selective Growth Inhibitor Derived from Liquid Culture of Cordyceps $\mathrm{m}$ ilitaris against Clostridium spp. Journal of agricultural and food chemistry, 48(7), 2744-2748. http://dx.doi.org/10.1021/jf990862n

Al-Fatimi, M., Wurster, M., Kreisel, H., Lindequist, U. 2005. Antimicrobial, cytotoxic and antioxidant activity of selected basidiomycetes from Yemen. Die Pharmazie-An International Journal of Pharmaceutical Sciences, 60(10), 776780 .

Alves, M.J., Ferreira, I.C.F.R., Dias, J., Teixeira, V., Martins, A., Pintado, M. 2012. A review on antimicrobial activity of mushrooms (Basidiomycetes) extracts and isolated compounds. Planta Med., 78, 1707-1718 http://dx.doi.org/10.1055/s-0032-1315370

Balakumar, R., Sivaprakasam, E., Kavitha, D., Sridhar, S., Kumar, J. S. 2011 Antibacterial and antifungal activity of fruit bodies of Phellinus mushroom extract. International J. Biosc., 1(3), 72-77.

Butler, M.S. 2004. The role of natural product chemistry in drug discovery. Journal of Natural Products, 67, 2141-2153. http://dx.doi.org/10.1021/np040106y

Clinical and Laboratory Standard Institute. Performance standard for antimicrobial susceptibility testing; informational supplement M100-S21. 21th ed. Wayne, PA: CLSI; 2009.

Demir, M. S., \& Yamac, M. (2008). Antimicrobial activities of basidiocarp, submerged mycelium and exopolysaccharide of some native Basidiomycetes strains. Journal of Applied Biological Sciences, 2(3), 89-93.

Gao, Y., Tang, W., Gao, H., Chan, E., Lan, J., Li, X., Zhou, S. 2005 Antimicrobial activity of medical mushrooms Ganoderma. Food Rev. Int., 21, 211-229. http://dx.doi.org/10.1081/fri-200051893

Heleno, S.A., Ferreira, I.C.F.R., Esteves, A.P., Ćirić, A., Glamočlija, J., Martins, A., Soković, M., Queiroz, M.J.R.P. 2013. Antimicorbial and demelanizing activity of Ganoderma lucidum extract, p-hydroxybenzoic and cinnamic acids and their synthetic acetylated glucuronide methyl esters. Food and Chemical Toxicology, 58, 95-100. http://dx.doi.org/10.1016/j.fct.2013.04.025

Kavitha, D., Balakumar, R., Sivaprakasam, E., Sridhar, S., Suresh, J. 2011. Antibacterial and antifungal potential of fruit body extracts from daldinia concentrica (bolton) cesati \& de notaris. International journal of pharmaceutical sciences and research, 2(9), 2376-2379.

Keller, C., Maillard, M., Keller, J., Hostettmann, K. 2002. Screening of European fungi for antibacterial, antifungal, larvicidal, molluscicidal, antioxidant and free radical scavenging activities and subsequent isolation of bioactive compounds. Pharmaceutical

biology, 40(7),

$518-525$

http://dx.doi.org/10.1076/phbi.40.7.518.14680

Keypour, S., Riahi, H., Moradali, M. F., Rafati, H. 2008. Investigation of the Antibacterial Activity of a Chloroform Extract of Ling Zhi or Reishi Medicinal Mushroom, Ganoderma lucidum (W. Curt.: Fr.) P. Karst. (Aphyllophoromycetideae), from Iran. International Journal of Medicinal Mushrooms, 10(4), 345-349. http://dx.doi.org/10.1615/intjmedmushr.v10.i4.70 Kneifel, H., Konig, W. A., Loeffler, W., \& Müller, R. (1977). Ophiocordin, an antifungal antibiotic of Cordyceps ophioglossoides. Archives of microbiology,113(1-2), 121-130. http://dx.doi.org/10.1007/bf00428591

Lam, K.S. 2007. New aspects of natural products in drug discovery. Trends in Microbiology, 15, 279-289. http://dx.doi.org/10.1016/j.tim.2007.04.001

Lindequist, U., Niedermeyer, T. H., \& Jülich, W. D. (2005). The pharmacological potential of mushrooms. Evidence-Based Complementary and Alternative Medicine, 2(3), 285-299. http://dx.doi.org/10.1093/ecam/neh107

Lindequist, U., Teuscher, E., \& Narbe, G. (1990). Neue Wirkstoffe aus Basidiomyceten. Z Phytother, 11, 139-49.

Molitoris, H. P. (1994). Mushrooms in medicine. Folia microbiologica, 39(2), 91-98. http://dx.doi.org/10.1007/bf02906801

Nikolovska-Nedelkoska, D., Atanasova-Pančevska, N., Amedi, H., Veleska, D. Ivanova, E., Karadelev, M., Kungulovski, D. 2013. Screening of antibacterial and antifungal activities of selected Macedonian wild mushrooms. Zbornik Matice srpske za prirodne nauke, (124), 333-340. http://dx.doi.org/10.2298/zmspn1324333n

Öztürk, M., Duru, M. E., Kivrak, Ş., Mercan-Doğan, N., Türkoglu, A., Özler, M A. 2011. In vitro antioxidant, anticholinesterase and antimicrobial activity studies on three Agaricus species with fatty acid compositions and iron contents: A comparative study on the three most edible mushrooms. Food and Chemica Toxicology, 49(6), 1353-1360. http://dx.doi.org/10.1016/j.fct.2011.03.019

Pala, S.A. and Wani, A.H. 2011. Mushrooms: the entities with multifarious medicinal properties. J. Pharm. Res., 165, 496-500.

Poucheret, P., Fons, F., \& Rapior, S. (2006). Biological and pharmacological activity of higher fungi: 20-year retrospective analysis. Cryptogamie Mycologie,27(4), 311.

Quereshi, S., Pandey, A.K., Sandhu, S.S. 2010. Evaluation of antibaterial activity of different Ganoderma lucisum extracts. J. Sci. Res., 3, 9-13.

Reinoso, R., Cajas-Madriaga, D., Martínez, M., San Martín, A., Pérez, C., Fajardo, V., Becerra, J. 2013. Biological Activity Of Macromycetes Isolated From Chilean Subantarctic Ecosystems. Journal of the Chilean Chemical Society, 58(4), 2016-2019. http://dx.doi.org/10.4067/s0717 $\underline{97072013000400024}$

Rosa, L. H., Machado, K. M. G., Jacob, C. C., Capelari, M., Rosa, C. A., \& Zani, C. L. (2003). Screening of Brazilian basidiomycetes for antimicrobial activity. Memórias do Instituto Oswaldo Cruz, 98(7), 967-974 http://dx.doi.org/10.1590/s0074-02762003000700019

Sheena, N., Ajith, T. A., Mathew, A.T., Janardhanan, K.K. 2003. Antibacterial activity of three macrofungi, Ganoderma lucidum, Navesporus floccosa and Phellinus rimosus occuring in South India. Pharm. Biol., 41, 564-567. http://dx.doi.org/10.1080/13880200390501226

Suay, I., Arenal, F., Asensio, F.J., Basilio, A., Cabello, A.M., Díez, M.T., García, J.B., González del Val, A., Gorrochategui, J., Hermández, P., Peláez, F., Vincente, M.F. 2000. Screening of basidiomycetes for antimicrobial activities. Antoine van Leeuwenhoek Journal of Microbiology, 78(2), 129-140. 
Sullivan, R., Smith, J.E., Rowan, N.J. 2006. Medicinal mushrooms and cancer therapy: translating a traditional practise into Western medicine. Perspect. Biol.

Med., 49, 159-170. http://dx.doi.org/10.1353/pbm.2006.0034

Venturini, M.E., Rivera, C.S., Gonzalez, C., Blanco, D. 2008. Antimicrobial activity of extracts of edible wild and cultivated mushrooms against foodborne bacterial strains. Journal of Food Protection, 8, 1701-1706.

Yoon, S. Y., Eo, S. K., Kim, Y. S., Lee, C. K., \& Han, S. S. (1994) Antimicrobial activity of Ganoderma lucidum extract alone and in combination with some antibiotics. Archives of pharmacal research, 17(6), 438-442. http://dx.doi.org/10.1007/bf02979122

Zheng, H., Maoqing, Y., Liqiu, X., Wenjuan, T., Lian, L., Guolin, Z. 2006. Purification and characterization of an antibacterial protein from the cultured mycelia of Cordyceps sinensis. Wuhan University J. Nat. Sci., 11, 709-714. http://dx.doi.org/10.1007/bf02836695 